\title{
Survey of preweaning dairy calf-rearing practices in Czech dairy herds
}

\author{
S. Staněk, ${ }^{*}$ V. Zink, $\dagger^{1}$ O. Doležal, $\ddagger$ and L. Štolc§ \\ *Department of Technology and Breeding Technique of Farm Animals, Přátelství 815, Institute of Animal Science, 10400 Prague 10 - Uhříněves, \\ Czech Republic \\ †Department of Cattle Breeding, Přátelství 815, Institute of Animal Science, 10400 Prague 10 - Uhříněves, Czech Republic \\ ‡Dairy Cattle Specialist, K Sokolovně 858, 10400 Prague 10-Uhříněves, Czech Republic \\ §Department of Animal Husbandry, Kamýcká 126, Czech University of Life Science, 16521 Prague 6 - Suchdol, Czech Republic
}

\begin{abstract}
It is important to describe weaknesses in rearing calves not only to improve their welfare, but also to detect areas where current scientific knowledge is poorly integrated into practice. A survey of preweaning calfrearing practices was conducted using a farmer questionnaire. The survey included 136 farms, representing $11.9 \%$ of all dairy cows in the Czech Republic. Mean herd size ( \pm standard deviation) was $326 \pm 131.4$ cows, and mean milk production $7,413 \pm 1,389.5 \mathrm{~kg}$ per cow per year. We evaluated 59 farms with Holsteins $(\mathrm{H})$ and 77 with the Czech Fleckvieh breed (C). The survey revealed that (1) calving in group pens predominated (67.6\% of farms); (2) no disinfection of calf navels occurred on $11.8 \%$ of herds; (3) pooled colostrum was fed on $15.4 \%$ of farms; (4) colostrum quality was controlled on only $44.1 \%$ of farms, and only $73.5 \%$ of farms had reserve colostrum stocks; (5) nonmarket waste milk was fed in $64.7 \%$ of herds but it was pasteurized in only in $6.8 \%$ of herds and acidified in $35.2 \%$ of herds; (6) milk replacer was mixed with nonmarket waste milk on $52.9 \%$ of farms; (7) $58.8 \%$ of farms enabled calves to obtain milk by sucking and $41.2 \%$ by drinking from a bucket; (8) the main criterion in weaning was calf age $(61.7 \%)$, followed by acceptance of starter and concentrated feed $(19.9 \%)$ and lack of housing capacity (18.4\%); and (9) newborn calves were individually housed on $96.7 \%$ of farms and group-housed on $3.3 \%$ of farms. The most marked differences in calf-rearing management between Holstein and Czech Fleckvieh farms were (1) a higher proportion of operations calving in tie-stalls or stanchions in $\mathrm{C}(6.5 \%)$ versus $\mathrm{H}(1.7 \%)$ farms; (2) a higher proportion of untreated navels on $\mathrm{C}$ (15.6\%) versus $\mathrm{H}(6.8 \%)$ farms; (3) a lower proportion of C $(11.7 \%)$ versus $\mathrm{H}(20.4 \%)$ farms feeding pooled colostrum; (4) a lower proportion of C (39\%) versus $\mathrm{H}$ (50.9\%) farms monitoring colostrum quality; (5) sucking milk from nipple buckets predominated (61\%) on C
\end{abstract}

Received July 31, 2013.

Accepted March 4, 2014.

${ }^{1}$ Corresponding author: vzink@seznam.cz farms, whereas drinking from an open bucket was most common $(64.4 \%)$ on $\mathrm{H}$ farms; (6) age was the main criterion in weaning calves of both breeds ( $\mathrm{C}$ farms: $55.8 \%$, H farms: $69.5 \%$ ), whereas the second most important criterion was lack of housing capacity $(28.6 \%$ of farms) on $\mathrm{C}$ farms and the amount of consumed starter (25.4\%) on $\mathrm{H}$ farms. We observed a difference in duration of colostrum period between $\mathrm{C}$ herds (median $5 \mathrm{~d}$ ) and $\mathrm{H}$ herds (median $4 \mathrm{~d}$ ). A tendency was observed for age of calves at weaning ( $\mathrm{C}$ herds: median at $9.1 \mathrm{wk}, \mathrm{H}$ herds: median at $10 \mathrm{wk}$ ).

Key words: calf, rearing, farm management, welfare

\section{INTRODUCTION}

The health of newborn and older calves is a result of balancing immune defenses, physical and metabolic stresses, nutrition, and environment (Heinrichs, 1993), and calf health affects the economics of a dairy operation (Campbell et al., 2007). Whether calves from the dairy herd are being reared as dairy herd replacements or for beef production, a good start in life is essential (Allen, 2004).

The key features of successful newborn dairy calf management are ensuring proper calving management, strategic navel antisepsis, prompt movement of the newborn calf to hygienic calf housing (Mee, 2008), and efficient colostrum management (McGuirk and Collins, 2004; Godden, 2008). In the weaning period, the amounts and management of milk feeding have immense effects on calf performance, behavior, health, and welfare (Heinrichs et al., 1995; Khan et al., 2007a). The decisive criterion determining a calf's preparedness for weaning should be its current consumption of solid feed (EFSA, 2006). The main purpose in individually housing calves is to minimize the spread of diseases and facilitate control over the animals' acceptance of starter (Bach et al., 2010), but good results have also been achieved among calves housed in pairs, which allows them greater space for movement and social opportunities without negative influence on health and growth (Chua et al., 2002). 
Table 1. Characteristics of 136 dairy farms surveyed compared with all farms in the Czech Republic

\begin{tabular}{lcccc}
\hline Item & Czech Republic & Sample & Holsteins & Czech Fleckvieh \\
\hline Dairy farms, no. & 1,296 & 136 & 59 & 77 \\
Cows, no. & 373,705 & 44,331 & 20,546 & 23,875 \\
Mean herd size, no. of cows & $273^{1}$ & $326 \pm 131.4$ & $348.2 \pm 134.8$ & $308.9 \pm 127$ \\
Mean $( \pm$ SD) milk production, $\mathrm{kg}$ /cow per year & $7,128^{1}$ & $7,413 \pm 1,389.5$ & $8,495.4 \pm 1,257.8$ & $6,585.3 \pm 786.5$ \\
\hline
\end{tabular}

${ }^{1}$ Data from the Czech-Moravian Breeders' Corporation (Kvapilík et al., 2012).

Due to the changes in modern farming, calf-rearing methods differ in individual countries and according to breed (EFSA, 2006); therefore, results from one country are not necessarily relevant for dairy farms in other countries (Svensson et al., 2006). In the United States, calf-rearing management practices differ not only between eastern and western states but also among herds of different sizes (USDA-APHIS, 2012). Vasseur et al. (2012) reported differences in dairy calf management practices between Central Europe States and Canada (Quebec); these were related to calving management and care of the newborn, colostrum management, calfdam separation, calf feeding, weaning, and calf housing. The first step in a strategy to improve animal welfare at the level of agricultural enterprises is to identify the main risks to animal welfare within a designated sampling of farms (Whay, 2007) or to describe those management methods in use that can most endanger animal welfare (Vasseur et al., 2010).

The goal of this study was to make the first extensive investigation in the Czech Republic to show strategies in farm management at calves from birth to weaning and to obtain relevant information about risk factors in this period of calf rearing. The results were analyzed for all investigated farms as well as separately for farms with Holstein and Fleckvieh breeds to define similarities and differences between those 2 breeds.

\section{MATERIALS AND METHODS}

\section{Description and Characteristics of Czech Climate and Dairy Herds}

The Czech Republic is situated in moderate temperature zone with evenly proportioned amount of rain during the year. According to Köppen's climate classification, the Czech Republic is classified as cfb (most of the country) and dfb (highlands; Tolasz et al., 2007). In the Czech Republic, the number of cows housed in tiestalls decreased from $77.5 \%$ of cows in 2000 to $11 \%$ of cows in 2010. In 2000, the average operation in the Czech Republic had 194 cows and 114 in stalls; in 2012, the average operation had 281 cows and 238 cows in stalls (Kvapilík et al., 2001, 2013).

\section{Selection and Description of Herds}

One hundred thirty-six farms were chosen for the survey, comprising the 2 main dairy cattle breeds in the Czech Republic: Holstein $(\mathbf{H})$, a milk breed, and Czech Fleckvieh (C), a dual-purpose breed. Together, these breeds account for $93 \%$ of the Czech dairy cow population. Farms with 100 to 600 cows were selected for the evaluation $(54.3 \%$ of operations in the Czech Republic have 100 to 500 cows). All evaluated farms were enrolled in production testing. Table 1 presents an overview of production data for the selected farms and for Czech farms as a whole.

\section{Data Collection and Description}

Data were collected from the 136 farms during 2012. The survey was conducted at breeding seminars focused on translating research findings into practice, with a dedicated time of $90 \mathrm{~min}$ set aside for farmers to provide the information using standardized questionnaires. Considering the great interest in these events and the absence of some herd managers, a few questionnaires were sent to these active participants electronically to be completed later. Ambiguities were generally resolved with the breeders immediately, and a few questionnaires were resolved by telephone or at a personal meeting with the farm manager. The topics included in the questionnaire were selected based upon reports of the United States National Animal Health Monitoring System (NAHMS) Dairy Heifer Raising, 2011 report (USDA-APHIS, 2012), NAHMS Dairy 2007 report (USDA-APHIS, 2010a,b), and the Czech Republic's national regulations Decree No. 2008/2004 Coll. on Minimum Standards for the Protection of Farm Animals, Decree No. 136/2004 Coll. on Details of Marking Animals and Their Registration and Registering of Farms and Entities as Defined by the Breeding Act (Czech Republic, 2004a,b). The questionnaire was divided into 7 groups of calf management practices (Table 2). Because some farmers may not want to admit their mistakes, some of the results reported herein, which are based on farmers' answers, may bear a farmer's bias and thus may not completely reflect 
Table 2. Studied parameters of calving and preweaning calf management

\begin{tabular}{ll}
\hline Area of management & Criterion (variable) \\
\hline $\begin{array}{l}\text { Calving management and } \\
\text { care of the newborn }\end{array}$ & $\begin{array}{l}\text { Period of housing the cow in a maternity pen before calving, calving area, use of a maternity pen, } \\
\text { type of maternity pen, separating the calf from the mother, number of navel treatments } \\
\text { with disinfectant (type and method) } \\
\text { Time of the first colostrum meal, colostrum origin, method, quantity, number and duration } \\
\text { of colostrum period, evaluation of colostrum quality, stocks of colostrum }\end{array}$ \\
Milk: type, use of pasteurization or acidification, use of waste milk \\
Milk feeding plan: quantity, number of meals, method of distribution, adjusting diet (winter) \\
Concentrate, hay, ensiled feed and water: age at access \\
Calf housing & $\begin{array}{l}\text { Individual housing: period, type, indoors and outdoors, materials, floor and bedding } \\
\text { Group housing }\end{array}$ \\
Criteria, type, and age \\
Weaning & $\begin{array}{l}\text { Method, age, dehorning personnel } \\
\text { Calf management activities } \\
\text { Time of marking calves }\end{array}$ \\
& Weighing after birth and at weaning \\
\hline
\end{tabular}

reality on the farms. Our comparison of several sample questions, however, indicates that most of the answers were in general agreement with reality.

\section{Statistical Analyses}

The acquired questionnaires were inspected upon collection. While compiling the database, all information was examined so that recording errors could be rectified with the relevant farm manager. Statistical analysis of qualitative questions was performed using descriptive statistics expressed in percentage terms. The normality of quantitative traits was verified by the Shapiro-Wilk test. The normality of testing date was not confirmed; therefore, the Mann-Whitney U-test was used to evaluate differences in quantitative traits between the 2 breeds in the present study by using Statistica 10 software (2011; Statsoft Inc., Tulsa, OK).

\section{RESULTS AND DISCUSSION}

\section{Calving, Calf-Dam Separation, and Calf Care}

The calving area was a part of the housing area for lactating dairy cows on $44.9 \%$ of all farms (48.1\% of $\mathrm{C}$ farms, and $40.7 \%$ of $\mathrm{H}$ farms), which can negatively influence milk production during natural photoperiod or long-day photoperiod during subsequent lactation (Dahl, 2008).

Risk of respiratory diseases is lower in calves born to cows in individual maternity pens than in those born in group pens (Svensson et al., 2003). Individual maternity pens were used on $28 \%$ of all surveyed farms, (30.5\% of $\mathrm{H}$ farms and $26 \%$ of $\mathrm{C}$ farms), and group maternity pens were used on $67.6 \%$ (Table 3). Cows and heifers were moved into the maternity pen $14.5 \mathrm{~d}$ (median) before calving, with $50 \%$ of farmers housing cows in the maternity pen for $\geq 14 \mathrm{~d}$ before expected birth (group maternity pens: $19 \mathrm{~d}$; individual maternity pens: $4 \mathrm{~d}$ before anticipated calving). The maternity pen should be used only for the calving itself, not as an area for housing dry cows or those in the transitional period.

In most of the surveyed Czech operations, early separation of calves from cows (median $4 \mathrm{~h}$ ) was a recommended strategy to eliminate the risk for failure of passive immunity transfer in calves (McGuirk and Collins, 2004; Trotz-Williams et al., 2008). A slightly higher proportion of calves were separated from their mothers before $12 \mathrm{~h}$ in $\mathrm{C}$ herds $(89.6 \%)$ compared with $\mathrm{H}$ herds $(84.8 \%)$. Across all surveyed farms (Table 3), $88.2 \%$ of calves had their navels treated, the preferred methods being dipping (39.7\%) and spraying (35.3\%). Calves' navels were treated only once in $66.9 \%$ of herds (64.9\% of $\mathrm{C}$ farms, $69.5 \%$ of $\mathrm{H}$ farms), despite the fact that repeated navel treatment is efficient prevention against navel inflammation (EFSA, 2012).

\section{Colostrum Feeding}

Proper management of colostrum feeding in calves is essential for their survival, health, and future productivity (e.g., McGuirk and Collins, 2004; Godden, 2008). In $66.9 \%$ of surveyed operations (Table 4), calves were fed colostrum from their own dams $(76.6 \%$ of $\mathrm{C}$ operations, $54.2 \%$ of $\mathrm{H}$ operations); in $15.4 \%$, calves were fed pooled colostrum. Across all operations, the median time of administering the first colostrum was $2 \mathrm{~h}$. Most operations (90.5\%) evaluated here administered first colostrum to calves within the first $6 \mathrm{~h}$ after birth (maximum time allowed in the Czech Republic). A significant difference $(P=0.001)$ was detected in the duration of the colostrum feeding period in $\mathrm{C}$ (median $5 \mathrm{~d}$ ) and $\mathrm{H}$ operations (median $4 \mathrm{~d}$ ).

The total amount of colostrum administered to calves from birth to $24 \mathrm{~h}$ was $5 \mathrm{~L}$ (all farms) and was provided 
Table 3. Survey responses regarding calving management and calf care in medium-large dairy herds (100 to 600 cows) in the Czech Republic

\begin{tabular}{|c|c|c|c|c|c|c|c|}
\hline Survey answer & Category & \multicolumn{2}{|c|}{ All herds } & \multicolumn{2}{|c|}{ Czech Fleckvieh } & \multicolumn{2}{|c|}{ Holstein } \\
\hline \multicolumn{8}{|l|}{ Calving pen } \\
\hline \multirow{2}{*}{ Use of calving pen } & Group & 92 & 67.6 & 52 & 67.5 & 40 & 67.8 \\
\hline & Tie stalls & 6 & 4.4 & 5 & 6.5 & 1 & 1.7 \\
\hline \multicolumn{8}{|l|}{ Calf care } \\
\hline \multirow{2}{*}{ Regarding method of navel treatment } & Drenching & 18 & 13.2 & 12 & 15.6 & 6 & 10.2 \\
\hline & No treatment & 16 & 11.8 & 12 & 15.6 & 4 & 6.8 \\
\hline
\end{tabular}

to calves twice on $47.8 \%$ of farms and 3 times on $41.2 \%$ of farms. A bottle with teat was used for feed colostrum in $77.1 \%$ of surveyed farms, whereas $10.3 \%$ used an open bucket; other methods of colostrum feeding are presented in Table 4. Half of the investigated farmers described using an esophageal tube for calves with low vitality (e.g., after dystocia).

In our survey, only $44.1 \%$ of farmers evaluated the quality of colostrum (39\% of $\mathrm{C}$ farms, $50.9 \%$ of $\mathrm{H}$ farms). All of those farmers used a colostrometer; opti-

Table 4. Survey responses regarding colostrum management and milk nutrition in medium-large dairy herds (100 to 600 cows) in the Czech Republic

\begin{tabular}{|c|c|c|c|c|c|c|c|}
\hline Survey item & Category & \multicolumn{2}{|c|}{ All herds } & \multicolumn{2}{|c|}{ Czech Fleckvieh } & \multicolumn{2}{|c|}{ Holstein } \\
\hline \multicolumn{8}{|l|}{ Colostrum management } \\
\hline \multirow{2}{*}{ Colostrum from primiparous cows } & Sometimes & 63 & 46.3 & 34 & 44.2 & 29 & 49.2 \\
\hline & Always & 62 & 45.6 & 37 & 48 & 25 & 42.3 \\
\hline Origin of colostrum & From the dam & 91 & 66.9 & 59 & 76.6 & 32 & 54.2 \\
\hline \multirow{4}{*}{ Method of colostrum feeding } & Plastic bottles with nipple & 33 & 24.2 & 17 & 22.1 & 16 & 27.1 \\
\hline & Open bucket & 14 & 10.3 & 4 & 5.2 & 10 & 16.9 \\
\hline & Bucket with nipple & 12 & 8.8 & 7 & 9.1 & 5 & 8.5 \\
\hline & Esophageal tube & 5 & 3.7 & 1 & 1.3 & 4 & 6.8 \\
\hline Using esophageal tube for calves & Yes & 68 & 50 & 39 & 50.6 & 29 & 49.2 \\
\hline with low vitality & No & 68 & 50 & 38 & 49.4 & 30 & 50.8 \\
\hline \multicolumn{8}{|l|}{ Milk nutrition } \\
\hline \multirow[t]{5}{*}{ Type of liquid milk diet } & Milk replacer & 48 & 35.3 & 28 & 36.4 & 20 & 33.9 \\
\hline & Pooled colostrum & 8 & 5.9 & 2 & 2.6 & 6 & 10.2 \\
\hline & $\begin{array}{l}\text { Pooled colostrum with milk } \\
\text { replacer }\end{array}$ & 34 & 25 & 22 & 28.6 & 12 & 20.3 \\
\hline & Waste milk & 8 & 5.9 & 3 & 3.8 & 5 & 8.5 \\
\hline & $\begin{array}{l}\text { Waste milk with milk } \\
\text { replacer }\end{array}$ & 38 & 27.9 & 22 & 28.6 & 16 & 27.1 \\
\hline \multirow[t]{2}{*}{ Pasteurization of milk } & Yes & 6 & 6.8 & 4 & 8.2 & 2 & 5.1 \\
\hline & No & 82 & 93.2 & 45 & 91.8 & 37 & 94.9 \\
\hline \multirow[t]{2}{*}{ Acidification of milk } & Yes & 31 & 35.2 & 17 & 34.7 & 14 & 35.9 \\
\hline & No & 57 & 64.8 & 32 & 65.3 & 25 & 64.1 \\
\hline \multirow[t]{3}{*}{ Feeding method } & Automatic feeding system & 3 & 2.2 & 2 & 2.6 & 1 & 1.7 \\
\hline & Nipple on a fixed platform & 9 & 6.6 & 8 & 10.4 & 1 & 1.7 \\
\hline & Open bucket & 56 & 41.2 & 18 & 23.4 & 38 & 64.4 \\
\hline
\end{tabular}


cal and digital refractometers were not used on any operation, despite their practical advantages and research findings showing that they work well in estimating IgG content in the first bovine colostrum (e.g., Bielmann et al., 2010; Quigley et al., 2013). Colostrum stocks are necessary when a cow cannot be milked for health reasons (such as milk fever), dies, or when the colostrum is found by evaluation to be of low quality (low IgG content) or adulterated (mastitis, blood). In total, 73.5\% of all breeders had frozen stocks of colostrum (Table 4). Insufficient stocks of colostrum indicate insufficient knowledge as to the importance of timely feeding of calves with colostrum.

\section{Marking and Weighing Calves}

Calves in the Czech Republic must be marked with permanent ear tags no later than $20 \mathrm{~d}$ after birth, and an unmarked calf must not leave the farm where it was born (Decree No. 136/2004 Coll.; Czech Republic, 2004a). The median age for marking calves was $2 \mathrm{~d}$. Across all evaluated operations, calves were weighed in just $2.2 \%$ of herds (Table 5), and $35.3 \%$ of all operations weighed calves at weaning or before moving them to other facilities.

\section{Disbudding}

According to ALCASDE (2009), 81.5\% of dairy cattle in countries of the European Union are dehorned $(82 \%$ in free housing and $52 \%$ in tie stalls or stanchions). In the Czech dairy herds surveyed, calves were disbudded in $96.3 \%$ of all operations at a median age of $4.3 \mathrm{wk}$ (Table 6). Cauterizing by hot iron was the most-used method (77.9\% of all herds) of disbudding calves. In the Czech Republic, calves may be dehorned up to 4 wk of age without using analgesia or anesthesia by both veterinarians and veterinary technicians (gradu-

Table 5. Survey responses regarding parameters of housing, weaning strategies, weighing, and dehorning of calves in medium-large dairy herds (100 to 600 cows) in the Czech Republic

\begin{tabular}{|c|c|c|c|c|c|c|c|}
\hline \multirow[b]{2}{*}{ Survey item } & \multirow[b]{2}{*}{ Category } & \multicolumn{2}{|c|}{ All herds } & \multicolumn{2}{|c|}{$\begin{array}{c}\text { Czech } \\
\text { Fleckvieh }\end{array}$} & \multicolumn{2}{|c|}{ Holstein } \\
\hline & & No. & $\%$ & No. & $\%$ & No. & $\%$ \\
\hline \multicolumn{8}{|l|}{ Housing } \\
\hline \multirow[t]{3}{*}{ Housing of calves after birth } & Individual pens & 34 & 22.4 & 21 & 23.9 & 13 & 20.3 \\
\hline & Individual hutches & 113 & 74.3 & 64 & 72.7 & 49 & 76.6 \\
\hline & Group hutches & 5 & 3.3 & 3 & 3.4 & 2 & 3.1 \\
\hline \multirow{3}{*}{ Housing technology used } & Shelter not at the barn & 25 & 16.4 & 10 & 11.4 & 15 & 23.4 \\
\hline & Calf barns & 9 & 5.9 & 7 & 8 & 2 & 3.1 \\
\hline & Dairy cow barns & 7 & 4.7 & 7 & 8 & - & - \\
\hline \multirow[t]{4}{*}{ Materials of housing construction } & Wood & 44 & 29 & 23 & 26.2 & 21 & 32.8 \\
\hline & Plastic & 93 & 61.2 & 56 & 63.6 & 37 & 57.8 \\
\hline & Metal & 7 & 4.6 & 6 & 6.8 & 1 & 1.6 \\
\hline & Metal construction and fabric & 8 & 5.2 & 3 & 3.4 & 5 & 7.8 \\
\hline Weaning method & Abruptly weaning & 45 & 33.1 & 24 & 31.2 & 21 & 35.6 \\
\hline \multicolumn{8}{|l|}{ Weighing of calves } \\
\hline \multirow[t]{2}{*}{ Weighing after birth } & Yes & 3 & 2.2 & 1 & 1.3 & 2 & 3.4 \\
\hline & No & 133 & 97.8 & 76 & 98.7 & 57 & 96.6 \\
\hline \multirow{2}{*}{ Weighing after weaning } & Yes & 48 & 35.3 & 30 & 39 & 18 & 30.5 \\
\hline & No & 88 & 64.7 & 47 & 61 & 41 & 69.5 \\
\hline \multicolumn{8}{|l|}{ Dehorning of calves } \\
\hline \multirow[t]{2}{*}{ Dehorning } & Yes & 131 & 96.3 & 73 & 94.8 & 58 & 98.3 \\
\hline & No & 5 & 3.7 & 4 & 5.2 & 1 & 1.7 \\
\hline \multirow[t]{4}{*}{ Dehorning personnel } & Farm managers & 93 & 71 & 54 & 74 & 39 & 67.3 \\
\hline & Farm personal & 28 & 21.4 & 17 & 23.2 & 11 & 19 \\
\hline & Veterinary & 7 & 5.3 & 1 & 1.4 & 6 & 10.3 \\
\hline & Veterinary technicians & 3 & 2.3 & 1 & 1.4 & 2 & 3.4 \\
\hline Methods of disbudding & Electric cauterizing irons & 63 & 48.1 & 35 & 48 & 28 & 48.3 \\
\hline
\end{tabular}


ates of veterinary secondary schools). At over $4 \mathrm{wk}$ of age, calves may be dehorned only by veterinarians using analgesia or anesthesia. The proportion done by veterinary technicians and veterinarians was only $7.6 \%$ in all operations surveyed. The proportion of farms on which veterinarians and veterinary technicians did this work was higher in $\mathrm{H}$ operations $(13.7 \%)$ than in $\mathrm{C}$ operations $(2.8 \%)$.

\section{Calf Feeding}

Calves were fed milk replacer on $35.3 \%$ of all farms, fed waste milk blended with milk replacer on $27.9 \%$ of farms, and fed pooled colostrum blended with milk replacer on $25 \%$ of farms (Table 4). Problems with feeding a farm's nonmarket waste milk can include not only its inconsistent quality but also high level of microbial contamination (Moore et al., 2009). Bacterial contamination of nonmarket waste milk can be reduced by pasteurization (Elizondo-Salazar et al., 2010) or acidification. Of 88 farms (from the total of 136 farms surveyed) feeding waste milk, only $6.8 \%$ pasteurized the milk, whereas $35.2 \%$ of farms acidified it, most frequently with formic acid. Calves were not fed marketable milk on any of the farms evaluated. The milk feeding plan used in the surveyed herds was a median of $6 \mathrm{~L}$ of milk or milk replacer per day given in 2 meals during the first week, $6 \mathrm{~L}$ in 2 meals between the first and the last week before weaning, and $5.7 \mathrm{~L}$ in 2 meals during the last week of the milk feeding period. On $58.8 \%$ of all farms, calves were allowed to feed on milk or replacer by sucking, whereas on $41.2 \%$ of farms, calves drank from an open bucket (Table 4). On C farms, feeding of calves with nipple buckets predominated ( $61 \%$ of operations), whereas on $\mathrm{H}$ farms, drinking from buckets was predominant (64.4\% of operations). Bucket-fed calves are unable to perform their natural sucking behavior, whereas teat-based milk feeding systems provide such an opportunity (Vasseur et al., 2010). Nursing cows were not used on any farms in our survey. Farm management strategies to eliminate the negative influence of cold stress on the growth and health of calves in winter and early spring include more intensive feeding and increasing the intake of energy in the diet (Nonnecke et al., 2009). Out of 88 farms where the milk diet was adjusted in winter, $64.3 \%$ increased the volume of daily milk or milk replacer (C farms $70.8 \%$, $\mathrm{H}$ farms $50 \%$ ), $28.4 \%$ of farms included one extra feeding, and $53.4 \%$ of farms increased the concentration of the milk replacer.

A smooth transition from milk feeding to consumption of solid feed (forages and grains) allows the transition from simple stomach digestion to functioning digestion within the rumen; this is crucial for successful calfrearing, especially in regard to calf health and growth (Khan et al., 2007b, 2011). Calves on $97.1 \%$ of all farms surveyed had access to starter feed or concentrated feeds at a median age of $5 \mathrm{~d}$ after birth. Hay was provided by $94.1 \%$ of all farms after $56 \mathrm{~d}$ of age (C farms: $50 \mathrm{~d}$, $\mathrm{H}$ farms: $60 \mathrm{~d}$; $P=0.32$ ). Ensiled feed (corn and hay silage or TMR) was provided to unweaned calves before weaning on $58.8 \%$ of all farms and starting at a median $68 \mathrm{~d}$ of age (C farms: $63 \mathrm{~d}, \mathrm{H}$ farms: $70 \mathrm{~d} ; P=0.71$ ); that is, very close to weaning or soon after weaning. On $81.3 \%$ of farms where calves were fed ensiled feed before weaning, calves were housed in groups (C farms: $76.2 \%$, $\mathrm{H}$ farms: 86.8\%). Management of calf feeding should also include ad libitum intake of water to maximize the intake of starter and growth, especially when calves are fed restrictive milk diet (Kertz et al., 1984). Water was provided to calves on all 136 farms during the milk feeding period (Table 6), starting at $3 \mathrm{~d}$ of age.

\section{Weaning}

Dairy calves should be weaned in accordance with their current consumption of dry feed, not just on the basis of their age or weight (EFSA, 2006). Age was the decisive criterion for weaning on $61.7 \%$ of farms, amount of starter was the decisive criterion on $19.9 \%$ of farms, and an insufficiency of free housing capacity for preweaning calves was the decisive criterion on $18.4 \%$ of all surveyed farms (Table 5). On C farms, the second most common criterion was lack of housing capacity $(28.6 \%)$.

Intake of starter and incremental growth are greater in calves weaned gradually compared with calves weaned abruptly (Sweeney et al., 2010). Gradual weaning of calves was more common $(66.9 \%)$ than abrupt weaning (Table 5) in our survey. In gradually weaned calves, the predominant method was to decrease the daily volume of milk or replacer, as reported by $62.6 \%$ of all farms (C farms: $66 \%, \mathrm{H}$ farms: $57.9 \%$ ). Another method practiced on the remaining $37.4 \%$ of surveyed farms (C farms: 34\%, $\mathrm{H}$ farms: $42.1 \%$ ) was a decrease in daily volume fed and concurrent decrease in the number of daily feedings. The median age of calves at weaning was 9.3 wk across all farms, and a tendency $(P$ $=0.09$ ) was observed between age of calves at weaning on $\mathrm{C}$ (9.1 wk) and $\mathrm{H}$ (10 wk) operations.

\section{Housing}

Group housing of calves is beneficial in regard to its effects on social behavior, whereas individual housing is preferred from the perspective of infections and diseas- 
Table 6. Quantitative parameters of the survey in calf rearing in the Czech Republic in medium-large dairy herds (100 to 600 cows) in the Czech Republic

\begin{tabular}{|c|c|c|c|c|c|c|c|c|c|c|}
\hline \multirow[b]{2}{*}{ Survey item } & \multicolumn{3}{|c|}{ All herds } & \multicolumn{3}{|c|}{ Czech Fleckvieh } & \multicolumn{3}{|c|}{ Holstein } & \multirow[b]{2}{*}{$P$-value } \\
\hline & No. & Median & $\mathrm{MAD}^{2}$ & No. & Median & MAD & No. & Median & MAD & \\
\hline \multicolumn{11}{|l|}{ Calving pen } \\
\hline $\begin{array}{l}\text { Moving of cows in maternity pens before calving, d } \\
\text { Calf separation }\end{array}$ & 136 & 14.5 & 9.64 & 77 & 14 & 10.37 & 59 & 15 & 8.89 & 0.89 \\
\hline $\begin{array}{l}\text { Calt separation } \\
\text { Time of separation calves from own dam, } \mathrm{h}\end{array}$ & \multicolumn{10}{|c|}{ Calf separation } \\
\hline \multicolumn{11}{|l|}{ Colostrum management } \\
\hline First colostrum meal, h & 136 & 2 & 1.48 & 77 & 2 & 0 & 59 & 2 & 1.48 & 0.92 \\
\hline Colostrum quantity during $0-6 \mathrm{~h}, \mathrm{~L}$ & 136 & 2.25 & 0.37 & 77 & 2 & 0.74 & 59 & 2.5 & 0.74 & 0.66 \\
\hline Colostrum quantity during $6-24 \mathrm{~h}, \mathrm{~L}$ & 136 & 2.5 & 0.74 & 77 & 2.5 & 0.74 & 59 & 3 & 1.48 & 0.19 \\
\hline Total colostrum quantity during $0-24 \mathrm{~h}, \mathrm{~L}$ & 136 & 5 & 1.48 & 77 & 5 & 1.48 & 59 & 5 & 1.48 & 0.41 \\
\hline Colostrum meals during 0-24 h, no. & 136 & 3 & 1.48 & 77 & 3 & 1.48 & 59 & 2 & 0 & 0.57 \\
\hline Duration of colostrum feeding, d & 136 & 5 & 1.48 & 77 & 5 & 1.48 & 59 & 4 & 1.48 & $0.001^{* *}$ \\
\hline \multicolumn{11}{|l|}{ Navel disinfection } \\
\hline $\begin{array}{l}\text { Number of treatments of navel, no. } \\
\text { Dehorning }\end{array}$ & 120 & 1 & 0 & 65 & 1 & 0 & 55 & 1 & 0 & 0.38 \\
\hline \multicolumn{11}{|l|}{ Dehorning } \\
\hline \multicolumn{11}{|l|}{ Nutrition } \\
\hline Quantity of milk/milk substitute per day during first week, L & 136 & 6 & 1.48 & 77 & 6 & 1.48 & 59 & 6 & 1.48 & 0.71 \\
\hline Quantity of milk/milk substitute per day between first and last week, L & 136 & 6 & 1.48 & 77 & 6 & 1.48 & 59 & 6 & 1.48 & 0.84 \\
\hline Quantity of milk/milk substitute per day during last week, L & 136 & 5.7 & 2.52 & 77 & 5 & 1.48 & 59 & 6 & 2.96 & 0.55 \\
\hline Total volume of liquid milk diet per calf, L & 136 & 399 & 118.61 & 77 & 399 & 117.12 & 59 & 394 & 120.10 & 0.51 \\
\hline Age at milk replacer feeding, $d$ & 120 & 6 & 1.48 & 72 & 6 & 1.48 & 48 & 6 & 1.48 & 0.19 \\
\hline Age at concentrate access, $\mathrm{d}$ & 133 & 5 & 2.96 & 76 & 5 & 2.96 & 57 & 4 & 1.48 & 0.21 \\
\hline Age at hay access, $d$ & 128 & 56 & 20.77 & 75 & 50 & 29.65 & 53 & 60 & 14.82 & 0.32 \\
\hline Age at silage feed access, $\mathrm{d}$ & 136 & 68 & 17.79 & 77 & 63 & 19.27 & 59 & 70 & 14.82 & 0.71 \\
\hline Age at water access, d & 136 & 3 & 2.96 & 77 & 4 & 2.96 & 59 & 3 & 2.96 & 0.51 \\
\hline \multicolumn{11}{|l|}{ Grouping of calves } \\
\hline Grouping of calves, wk & 136 & 8.1 & 2.08 & 77 & 8 & 1.48 & 59 & 8.6 & 2.22 & 0.17 \\
\hline $\begin{array}{l}\text { Weaning } \\
\text { Age at weaning, wk }\end{array}$ & 136 & 9.3 & 1.78 & 77 & 9.1 & 1.48 & 59 & 10 & 2.07 & $0.09 *$ \\
\hline
\end{tabular}

$\stackrel{D^{2}}{\Sigma} \quad{ }^{1}$ Mann-Whitney U-test (Wilcoxon rank sum test with continuity correction).

ஸे $\quad{ }^{2} \mathrm{MAD}=$ median absolute deviation. 
es. In the Czech Republic, no calf may be confined to an individual pen after the age of $8 \mathrm{wk}$ (except isolation pens for sick calves). Calves were housed individually on $96.7 \%$ of Czech farms for a median of 8.1 wk (Table $5)$; calves in $\mathrm{H}$ operations were shifted into groups (8.6 wk) slightly later than calves in $\mathrm{C}$ operations (8 wk), although this difference was not significant $(P=$ $0.17)$. Most calves ( $74.3 \%$ of all farms) were housed in individual hutches. The most widespread materials for individual housing of calves were plastic $(61.2 \%)$ and wood (29\%), with plastic being easier to clean and disinfect than wood (Table 5). The calves were moved into groups before weaning on $68.4 \%$ of farms (C farms: $68.8 \%$, H farms: $67.8 \%$ ). Tied housing was not used on any of the farms. Calves were housed outdoors on $54.6 \%$ of all operations, in shelters at the barn in $18.4 \%$, in shelters not at the barn in $16.4 \%$, in calf barns in $5.9 \%$, and in dairy cow barns in $4.7 \%$. No $\mathrm{H}$ calves were housed in milk cow barns, whereas $8 \%$ of $\mathrm{C}$ calves were housed in dairy cow barns. A higher proportion of calves in $\mathrm{H}$ operations were housed in shelters not at the barn (23.4\%), whereas just $11.4 \%$ of $\mathrm{C}$ operations housed calves in shelters not at the barn.

Hutches and pens for calves were placed on reinforced surfaces (concrete floor, panel platforms, or asphaltconcrete areas) on $80.9 \%$ of farms and were placed on soil on $19.1 \%$ of farms. Long wheat straw has traditionally been used as bedding for rearing calves (Panivivat et al., 2004) and was used exclusively on all farms. Bedding was not replaced during the rearing period in $94.5 \%$ of operations, although additional straw was regularly added for the calves.

\section{CONCLUSIONS}

The objective of this survey was to identify weak areas of dairy calf-rearing during the milk nutrition period in dairy herds, doing so for operations generally and also according to the individual breeds raised (Czech Fleckvieh and Holstein). Management of the Czech Fleckvieh breed was found to differ from the Holstein operations only in the duration of the colostrum feeding period and we observed a tendency for length of milk feeding to differ between the 2 breeds (9.1 wk for $\mathrm{C}$ and 10 wk for $\mathrm{H}$ ). No other statistically significant differences were found between $\mathrm{C}$ and $\mathrm{H}$ operations. Research into calf-rearing during the preweaning period is one of the key elements for determining points of risk and identifying weaknesses and strengths in the area of feeding and management practices on dairy farms. Descriptions of weaknesses in calf-rearing practices provide opportunities for applying existing scientific and research findings in daily practice.

\section{ACKNOWLEDGMENTS}

This study was supported by a research plan of the Ministry of Agriculture of the Czech Republic (Prague, Czech Republic; MZE0002701404), a research grant from the National Agency for Agricultural Research (Prague, Czech Republic; NAZV QI91A238), and a research plan of the Ministry of Education, Youth and Sports of the Czech Republic (Prague, Czech Republic; SGRANT). We thank all the dairy farmers for their active participation in the survey.

\section{REFERENCES}

ALCASDE (Alternatives to Castration and Dehorning). 2009. Report on dehorning practices across EU member states. Accessed Jan. 11, 2013. http://ec.europa.eu/food/animal/welfare/farm/docs/ calves_alcasde_D-2-1-1.pdf.

Allen, D. M. 2004. Calf rearing. Page 3 in Part 1: Management: Bovine Medicine: Diseases and Husbandry of Cattle. 2nd ed. Blackwell Publishing, Oxford, UK.

Bach, A., J. Ahedo, and A. Farrer. 2010. Optimizing weaning strategies of dairy replacement calves. J. Dairy Sci. 93:413-419.

Bielmann, V., J. Gillan, N. R. Perkins, A. L. Skidmore, S. Godden, and K. E. Leslie. 2010. An evaluation of Brix refractometry instruments for measurement of colostrum quality in dairy cattle. J. Dairy Sci. 93:3713-3721.

Campbell, J. M., L. E. Russell, J. D. Crenshaw, E. M. Weaver, S. Godden, J. D. Quigley, J. Coverdale, and H. Tyler. 2007. Impact of irradiation and immunoglobulin $\mathrm{G}$ concentration on absorption of protein and immunoglobulin $\mathrm{G}$ in calves fed colostrum replacer. J. Dairy Sci. 90:5726-5731.

Chua, B., E. Coenen, J. Van Delen, and D. M. Weary. 2002. Effects of pair versus individual housing on the behavior and performance of dairy calves. J. Dairy Sci. 85:360-364.

Czech Republic. 2004a. Vyhláška MZe č. 136/2004 Sb., kterou se stanoví podrobnosti označování zvírat a jejich evidence a evidence hospodářství a osob stanovených plemenářským zákonem. Sbírka zákonů 2004, částka 44. Ministry of Agriculture of the Czech Republic, Prague, Czech Republic.

Czech Republic. 2004b. Vyhláška MZe č. 208/2004 Sb. o minimálních standardech pro ochranu hospodářských zvírat. Sbírka zákonů 2004, částka 69. Ministry of Agriculture of the Czech Republic, Prague, Czech Republic.

Dahl, G. E. 2008. Effects of short day photoperiod on prolactin signaling in dry cows: A common mechanism among tissues and environments? J. Anim. Sci. 86(Suppl. 1):10-14. http://dx.doi. org/10.2527/jas.2007-0311.

EFSA (European Food Safety Authority). 2006. EFSA Panel on Animal Health and Welfare (AHAW): Opinion on "The risks of poor welfare in intensive calf farming systems. An update of the Scientific Veterinary Committee Report on the Welfare of Calves". Accessed Jan. 20, 2013. http://www.efsa.europa.eu/en/efsajournal/ doc/366.pdf.

EFSA (European Food Safety Authority). 2012. EFSA Panel on Animal Health and Welfare (AHAW): Scientific opinion on the welfare of cattle kept for beef production and the welfare in intensive calf farming systems. Accessed Feb. 2, 2013. http://www.efsa.europa. eu/en/efsajournal/doc/2669.pdf.

Elizondo-Salazar, J. A., C. M. Jones, and A. J. Heinrichs. 2010. Evaluation of calf milk pasteurization systems on 6 Pennsylvania dairy farms. J. Dairy Sci. 93:5509-5513.

Godden, S. 2008. Colostrum management for dairy calves. Vet. Clin. North Am. Food Anim. Pract. 24:19-39.

Heinrichs, A. J. 1993. Raising dairy replacements to meet the needs of the 21st century. J. Dairy Sci. 76:3179-3187. 
Heinrichs, A. J., S. J. Wells, and W. C. Losinger. 1995. A study of the use of milk replacers for dairy calves in the United States. J. Dairy Sci. 78:2831-2837.

Kertz, A. F., L. F. Reutzel, and J. H. Mahoney. 1984. Ad libitum water intake by neonatal calves and its relationship to calf starter intake, weight gain, feces score, and season. J. Dairy Sci. 67:2964-2969.

Khan, M. A., H. J. Lee, W. S. Lee, H. S. Kim, K. S. Ki, T. Y. Hur, G. H. Suh, S. J. Kang, and Y. J. Choi. 2007a. Structural growth, rumen development, and metabolic and immune responses of Holstein male calves fed milk through step-down and conventional methods. J. Dairy Sci. 90:3376-3387.

Khan, M. A., H. J. Lee, W. S. Lee, H. S. Kim, S. B. Kim, K. S. Ki, S. J. Park, J. K. Ha, and Y. J. Choi. 2007b. Starch source evaluation in calf starter: I. Feed consumption, body weight gain, structural growth, and blood metabolites in Holstein calves. J. Dairy Sci. 90:5259-5268.

Khan, M. A., D. M. Weary, and M. A. G. von Kyserlingk. 2011. Effects of milk ration on solid feed intake, weaning, and performance in dairy heifers. J. Dairy Sci. 94:1071-1081.

Kvapilík, J., et al. 2000. Chov skotu v České republice - hlavní výsledky a ukazatele za rok 1999. Czech-Moravian Breeders Society, Breeders' Association of Czech Pied Cattle, Černostrakatého Cattle Breeders Association, Association of Breeders of Beef Cattle, Prague, Czech Republic.

Kvapilík, J., Z. Růžička, and P. Bucek. 2012. Chov skotu v České republice. Czech-Moravian Breeders Society, Research Institute of Animal Science Prague-Uhríněves, Breeders' Association of Czech Pied Cattle, Breeders Association of Holstein Cattle in the Czech Republic, Czech Beef Cattle Breeders Association, Prague, Czech Republic

Kvapilík, J., Z. Růžička, and P. Bucek. 2013. Chov skotu v České republice. Czech-Moravian Breeders Society, Breeders' Association of Czech Pied Cattle, Breeders Association of Holstein Cattle in the Czech Republic, Czech Beef Cattle Breeders Association, Prague, Czech Republic.

McGuirk, S. M., and M. Collins. 2004. Managing the production, storage, and delivery of colostrum. Vet. Clin. North Am. Food Anim. Pract. 20:593-603.

Mee, J. F. 2008. Newborn dairy calf management. Vet. Clin. North Am. Food Anim. Pract. 24:1-17.

Moore, D. N., J. Taylor, M. L. Hartman, and W. M. Sischo. 2009. Quality assessments of waste milk at a calf ranch. J. Dairy Sci. 92:3503-3509.

Nonnecke, B. J., M. R. Foote, B. L. Miller, M. Fowler, T. E. Johnson, and R. L. Horst. 2009. Effects of chronic environmental cold on growth, health, and select metabolic and immunologic responses of preruminant calves. J. Dairy Sci. 92:6134-6143.

Panivivat, R., E. B. Kegley, J. A. Pennington, D. W. Kellogg, and S. L. Krumpelman. 2004. Growth performance and health of dairy calves bedded with different types of materials. J. Dairy Sci. $87: 3736-3745$.
Quigley, J. D., A. Lago, C. Chapman, P. Erickson, and J. Polo. 2013. Evaluation of the Brix refractometer to estimate immunoglobulin G concentration in bovine colostrum. J. Dairy Sci. 96:1148-1155.

Svensson, C., A. Linder, and S.-O. Olsson. 2006. Mortality in Swedish dairy calves and replacement heifers. J. Dairy Sci. 89:4769-4777.

Svensson, C., K. Lundborg, U. Emanuelson, and S. O. Olsson. 2003. Morbidity in Swedish dairy calves from birth to 90 days of age and individual calf-level risk factors for infectious diseases. Prev. Vet. Med. 58:179-197.

Sweeney, B. C., J. Rushen, D. M. Weary, and A. M. de Passillé. 2010. Duration of weaning, starter intake, and weight gain of dairy calves fed large amounts of milk. J. Dairy Sci. 93:148-152.

Tolasz, R., R. Brázdil, O. Bulír, P. Dobrovolný, M. Dubrovský, L. Hájková, O. Halásová, J. Hostýnek, M. Janouch, M. Kohut, K. Krška, S. Křivancová, V. Květoň, Z. Lepka, P. Lipina, J. Macková, L. Metelka, T. Míková, Z. Mrkvica, M. Možný, J. Nekováŕ, L. Němec, J. Pokorný, J. D. Reitschläger, D. Richterová, J. Rožnovský, M. Repka, D. Semerádová, V. Sosna, M. Stříž, P. Šercl, H. Škáchová, P. Stěpánek, P. Štěpánková, M. Trnka, A. Valeriánová, J. Valter, K. Vaníček, F. Vavruška, V. Voženílek, T. Vráblík, M. Vysoudil, J. Zahradníček, I. Zusková, M. Žák, and Z. Žalud. 2007. Climate Atlas of Czechia. 1st ed. Czech Hydrometeorological Institute, Prague, Czech Republic.

Trotz-Williams, L. A., K. E. Leslie, and A. S. Peregrine. 2008. Passive immunity in Ontario dairy calves and investigation of its association with calf management practices. J. Dairy Sci. 91:3840-3849.

USDA-APHIS (Animal and Plant Health Inspection Service). 2010a Dairy 2007: Facility Characteristics and Cow Comfort on U.S. Dairy Operations, 2007. \#524.1210. USDA-APHIS-Veterinary Services, Centers for Epidemiology and Animal Health), Fort Collins, CO.

USDA-APHIS (Animal and Plant Health Inspection Service). 2010b. Dairy 2007: Heifer Calf Health and Management Practices on U.S Dairy Operations, 2007. \#550.0110. USDA-APHIS-Veterinary Services, Centers for Epidemiology and Animal Health), Fort Collins, CO.

USDA-APHIS (Animal and Plant Health Inspection Service). 2012 Dairy Heifer Raiser, 2011. \#613.1012. USDA-APHIS-Veterinary Services, Centers for Epidemiology and Animal Health), National Animal Health Monitoring System (NAHMS), Fort Collins, CO.

Vasseur, E., F. Borderas, R. I. Cue, D. Lefebvre, D. Pellerin, J. Rushen, K. M. Wade, and A. M. de Pasillé. 2010. A survey of dairy calf management practices in Canada that affect animal welfare. J. Dairy Sci. 93:1307-1315.

Vasseur, E., D. Pellerin, A. M. de Passillé, C. Winckler, B. J. Lensink, U. Knierim, and J. Rushen. 2012. Assessing the welfare of dairy calves: Outcome-based measures of calf health versus input-based measures of the use of risky management practices. Anim. Welf. $21: 77-86$.

Whay, H. R. 2007. The journey to animal welfare improvement. Anim. Welf. 16:117-122. 